\title{
PENGEMBANGAN POTENSI EKONOMI KAWASAN PESISIR SEDATI BERBASIS MASYARAKAT
}

\author{
Yudo Darmanto ${ }^{1)}$, Suning ${ }^{2}$ \\ 1) $\&^{2)}$ Program Studi Perencanaan Wilayah dan Kota, Fakultas Teknik Sipil dan Perencanaan \\ Universitas PGRI Adi Buana Surabaya \\ Email : yudo_scoot90@yahoo.co.id
}

\begin{abstract}
Abstrak
Kecamatan Sedati merupakan salah satu Kecamatan berpotensi di Kabupaten Sidoarjo. Potensi yang terdapat di Kecamatan Sedati ialah perikanan tangkap dan perikanan tambak. Potensi perikanan memberikan kontribusi terhadap pembangunan ekonomi di Kabupaten Sidoarjo secara umum. Penelitian ini bertujuan untuk mengidentifikasi pengembangan potensi ekonomi kawasan pesisir Sedati berbasis partisipasi masyarakat. Metode penelitian yang digunakan adalah metode deskriptif kuantitatif dan kualitatif. Teknik analisis yang digunakan adalah Analisis Skalogram dengan tujuan untuk mengetahui potensi ekonomi, Analisis Partisipasi Masyarakat untuk mengetahui tingkat partisipasi masyarakat dan Analisis SWOT-STEEP untuk menentukan strategi pengembangan potensi ekonomi. Hasil penelitian berdasarkan Analisis Skalogram menunjukkan bahwa Desa Kalanganyar adalah desa yang paling berpotensi dibandingkan desa pesisir lainnya di Kecamatan Sedati untuk potensi perikanan tambak. Hasil analisis partisipasi masyarakat menunjukkan bahwa tingkat partisipasi masyarakat kawasan pesisir Kecamatan Sedati berada pada level 2 Theraphy, yaitu inisiatif datang dari Pemerintah dan hanya satu arah. Hasil dari kombinasi matriks SWOT-STEEP menunjukkan prioritas utama yang harus ditingkatkan yaitu aspek sosial, dengan cara meningkatkan mutu dan kualitas sumber daya manusia masyarakat yang ada di kawasan pesisir Sedati.
\end{abstract}

Kata Kunci : Partisipasi masyarakat, Pesisir, Potensi ekonomi, Skalogram, STEEP-SWOT.

\begin{abstract}
Sub district of Sedati is one of potentially districts in Sidoarjo. The potencies of Sedati Sub district are about fisheries and fishing pond. The fisheries potential are contributing for economic development in Sidoarjo in general and specifically in the District Sedati. This study aims to identify the economic development potential of coastal areas Sedati based community participation. The method used is descriptive quantitative and qualitative methods. The analysis technique used scalogram analysis in order to determine the economic potential. The analysis of community participation used to determine the level of community participation and SWOTSTEEP Analysis to determine the strategy of potential economic development. The research results based on scalogram analysis shows that the most potential village is Kalanganyar village, compared to other coastal villages in Sedati, is the potential of fishery ponds. The results of the community participations analysis showed that the level of community participation in coastal areas of Sedati District are at level 2 Theraphy, the initiative came from the government and only one direction. The results of the combination SWOT-STEEP matrix shows that the main priority which is should be improved is the social aspect, by apply the way of improving the quality of human resources existing communities of coastal areas in Sedati.
\end{abstract}

Keywords: The communities participation, coastal areas, economic potencies, scalogram, STEEPSWOT 


\section{PENDAHULUAN}

Indonesia merupakan negara kepulauan, negara maritim, negara yang mempunyai kekayaan laut yang begitu melimpah. Tidak heran jika kawasan pesisir di Indonesia menjadi andalan sumber pendapatan masyarakat Indonesia. Wilayah pesisir dijelaskan secara umum oleh Beatly et al, (2002) bahwa pesisir adalah wilayah pertemuan antara ekosistem darat, ekosistem laut, dan ekosistem udara yang bertemu dalam suatu keseimbangan yang rentan.

Kabupaten Sidoarjo merupakan salah satu kabupaten yang ada di Provinsi Jawa Timur. Kabupaten ini berbatasan dengan Kota Surabaya dan Kabupaten Gresik di sebelah utara, Selat Madura di sebelah timur, Kabupaten Pasuruan di sebelah selatan, serta Kabupaten Mojokerto di sebelah barat. Kabupaten Sidoarjo dikenal sebagai penyangga utama Kota Surabaya dan termasuk kawasan Satuan Wilayah Pengembangan Gerbangkertosusila. Sektor industri di Sidoarjo berkembang cukup pesat karena lokasi yang berdekatan dengan pusat bisnis Jawa Timur (Surabaya), dekat dengan Pelabuhan Laut Tanjung Perak maupun Bandar Udara Juanda, memiliki sumber daya manusia yang produktif serta kondisi sosial politik dan keamanan yang relatif stabil menarik minat investor untuk menanamkan modalnya di Sidoarjo. Perikanan, industri dan jasa merupakan sektor perekonomian utama Sidoarjo. Selat Madura di sebelah Timur merupakan daerah penghasil perikanan, diantaranya ikan, udang, dan kepiting. Logo Kabupaten menunjukkan bahwa Udang dan Bandeng merupakan komoditi perikanan yang utama kota ini. Sidoarjo dikenal pula dengan sebutan "Kota Petis".

Wilayah pesisir Kecamatan Sedati merupakan salah satu wilayah Kabupaten Sidoarjo yang memiliki potensi sumberdaya perairan di bidang perikanan tangkap dan perikanan tambak. Pengembangan pemanfaatan potensi sumberdaya perairan pantai diarahkan untuk meningkatkan kesejahteraan masyarakat setempat sehingga dapat meningkatkan perekonomian masyarakat sekitar, dengan meningkatkan peran serta partisipasi masyarakat.
Pembangunan masa lalu dan sampai saat ini lebih menitikberatkan kepada eksploitasi daratan daripada lautan. Sehingga pembangunan wilayah pesisir relatif tertinggal dibandingkan wilayah daratan lainnya. Masyarakat pesisir (nelayan) relatif lebih miskin dibandingkan masyarakat lainnya. Kondisi ini diperburuk dengan posisi nelayan yang relatif lemah dibandingkan dengan profesi lainnya (Budiharsono, 2001).

Maka dari itu, potensi kekayaan laut yang ada di daerah kawasan pesisir kecamatan sedati bisa dijadikan sebagai salah satu andalan perekonomian masyarakat sekitar. Oleh karena itu diperlukan sebuah penelitian lebih lanjut mengenai potensi ekonomi kawasan pesisir di Kecamatan Sedati dalam upaya pengembangan ekonomi yang berbasis masyarakat. Tujuan penelitian ini adalah untuk mengkaji pengembangan potensi ekonomi kawasan pesisir Kecamatan Sedati berbasis masyarakat.

\section{METODE}

Metodologi yang digunakan dalam penelitian ini adalah dengan melakukan observasi di lokasi penelitian, untuk mengetahui potensi ekonomi kawasan pesisir di Kecamatan Sedati. Pengumpulan data dilakukan dengan wawancara secara terstruktur menggunakan responden yang telah ditentukan sebelumnya. Penentuan responden ini berdasarkan masyarakat yang bekerja sebagai nelayan dan petani tambak sehingga responden dapat memberikan data yang valid untuk mendukung penelitian.

Subjek populasi meliputi 5 desa di Kecamatan Sedati yang berada pada kawasan pesisir diantaranya : Desa Kalanganyar, Desa Tambak Cemandi, Desa Gisik Cemandi, Desa Banjar Kemuning, dan Desa Segoro Tambak. Penentuan sampel menggunakan sistem acak, tiap desa yang sudah disebutkan memiliki jumlah masyarakat yang bekerja sebagai nelayan dan petani tambak yang berbeda-beda. Penentuan sampel menghasilkan responden sebagai perwakilan dalam melakukan wawancara.

Analisis data dilakukan secara deskriptif kuantitatif dan kualitatif. Penggunaan metode deskriptif kuantitatif untuk mengidentifikasi potensi ekonomi, dilakukan dengan analisis 
Skalogram mengidentifikasi adanya kelengkapan persebaran sarana dan prasarana yang ada di masing-masing desa wilayah penelitian.

Penggunaan metode deskriptif kualitatif untuk mengidentifikasi tingkat partisipasi masyarakat, dilakukan dengan analisis tingkat pastisipasi masyarakat yang menggunakan tangga partisipasi dan pola pengembangan potensi ekonomi, dilakukan menggunakan analisis SWOT mengidentifikasi situasi internal dan ekternal berupa faktor-faktor yang menjadi kekuatan dan kelemahan dan faktorfaktor yang menjadi peluang dan ancaman yang ada di wilayah penelitian. Analisis STEEP merupakan matriks yang dikombinasikan dengan matriks analisis SWOT dengan melakukan pendekatan yang lebih komprehensif dalam membantu mengolah data dari fakta yang ada untuk dipecahkan dan dicarikan solusinya dengan mengidentifikasi aspek sosial, teknologi, ekonomi, ekologi, dan politik yang ada di wilayah penelitian.

\section{HASIL DAN PEMBAHASAN Analisis Skalogram}

Sasaran analisis dalam penelitian ini adalah 5 Desa yang ada di kawasan pesisir Kecamatan Sedati. Tabel di bawah ini akan menyajikan jumlah jenis dan unit sarana dan prasarana pembangunan atau fasilitas sosial ekonomi pada tiap Desa yang ada di wilayah penelitian ini yang disusun secara skalogram. Berdasarkan tabel dibawah ini tentang hirarki atau peringkat dimulai yang paling teratas sampai dengan peringkat terbawah.

Tabel 1. Hirarki Analisis Skalogram Wilayah Penelitian

\begin{tabular}{|c|c|c|c|c|c|c|c|c|c|c|c|c|c|c|c|c|}
\hline \multirow{2}{*}{ Desa } & \multicolumn{15}{|c|}{ Kriteria } & \multirow{2}{*}{ Jumlah } \\
\hline & 1 & 2 & 3 & 4 & 5 & 6 & 7 & 8 & 9 & 10 & 11 & 12 & 13 & 14 & 15 & \\
\hline Kalanganyar & 1 & 1 & 1 & 1 & 1 & 1 & 1 & 0 & 1 & 1 & 0 & 0 & 1 & 0 & 1 & 11 \\
\hline Segoro Tambak & 1 & 1 & 1 & 0 & 0 & 1 & 1 & 0 & 1 & 0 & 1 & 0 & 1 & 0 & 0 & 8 \\
\hline Gisik Cemandi & 0 & 1 & 1 & 0 & 0 & 1 & 1 & 0 & 1 & 0 & 0 & 1 & 0 & 0 & 1 & 7 \\
\hline Tambak Cemandi & 1 & 0 & 1 & 0 & 0 & 1 & 1 & 1 & 1 & 0 & 0 & 0 & 0 & 0 & 0 & 6 \\
\hline Banjar Kemuning & 0 & 1 & 1 & 0 & 0 & 1 & 1 & 0 & 1 & 0 & 0 & 0 & 0 & 0 & 0 & 5 \\
\hline
\end{tabular}

Sumber : Hasil Analisis, 2014

Keterangan : Kriteria Sarana Prasarana :

$\begin{array}{llll}1=\text { ada } & 1=\text { Taman bermain } & 8=\text { Gereja } \\ 0=\text { tidak ada } & 2=\text { Taman Kanak-kanak } & 9=\text { Kantor Desa } \\ & 3=\text { Sekolah Dasar } & 10=\text { Pasar } \\ 4 & =\text { SMP } & 11=\text { Poliklinik } \\ 5 & =\text { SMA } & 12=\text { TPI } \\ 6 & =\text { Masjid } & 13=\text { Lapangan } \\ 7 & =\text { Mushola } & 14=\text { Puskesmas }\end{array}$

Berdasarkan tabel 1. bahwa hanya Desa Kalanganyar yang memiliki jumlah unit fasilitas terbanyak. Desa Kalanganyar merupakan Desa yang memiliki jumlah penduduk yang paling banyak, sehingga kelengkapan sarana prasarana sangat diperlukan. Selain itu Desa Kalanganyar memiliki luas wilayah yang paling besar, sehingga desa ini memiliki fasilitas yang tidak dimiliki oleh desa lainnya.

Desa Kalanganyar merupakan desa yang berkembang, ditambah lagi Desa Kalanganyar terletak paling dekat dengan Kecamatan Sedati, mudah dijangkau dari Kota/ Kabupaten Sidoarjo. Dilihat dari akses jalannya Desa Kalanganyar yang paling berkembang, jadi dengan adanya akses yang mudah juga memudahkan untuk akses keluar masuk distribusi apapun. Dengan adanya akses yang mudah, juga mempengaruhi proses pemasaran dari potensi yang ada di Desa Kalanganyar. 


\section{Analisis Partisipasi Masyarakat}

Pengembangan potensi ekonomi berbasis masyarakat merupakan suatu alternatif yang diharapkan bisa mampu menjawab persoalan yang terjadi berdasarkan karakteristik sumber daya alam dan sumber daya manusia di wilayah penelitian ini. Dalam hal ini suatu komunitas mempunyai hak untuk dilibatkan atau mempunyai kewenangan secara langsung untuk membuat perencanaan, disesuaikan dengan kapasitas dan daya dukung sumber daya alam dengan ragam aktivitas masyarakat sekitar. Dengan adanya partisipasi masyarakat diharapkan masyarakat dapat lebih berperan secara aktif dan terlibat langsung dalam pemanfaatan potensi sumber daya alam lokal untuk menjamin dan menjaga kelestarian sumberdaya tersebut.

Berdasarkan hasil dari wawancara yang dilakukan di wilayah penelitian ada di 5 Desa, yaitu : Desa Kalanganyar, Desa Tambak Cemandi, Desa Gisik Cemandi, Desa Banjar
Kemuning, dan Desa Segoro Tambak, mayoritas masyarakat sekitar menggantungkan hidupnya kepada hasil tangkapan untuk para nelayan dan hasil budidaya untuk para petani tambak. Mayoritas masyarakat mendapatkan hasil yang cukup untuk memenuhi kebutuhan sehari-hari khususnya para nelayan.

Hasil tangkapan para nelayan adalah ikan bandeng, ikan dorang, ikan belanak, udang, kerang, dan kepiting. Komoditas tersebut yang diandalkan oleh para nelayan untuk dijual dan untuk memenuhi kebutuhan hidup sehari-hari. Mayoritas para nelayan dari hasil tangkapannya disetor kepada pengepul yang biasanya mereka sebut dengan juragan. Dari juragan tersebut para nelayan tidak tahu lagi hasil tangkapannya dipasarkan kemana. Pengepul/ juragan selanjutnya dari juragan ada yang dibawa ke restoran maupun pasar baik lokal maupun diluar Kabupaten Sidoarjo. Untuk lebih jelasnya bisa dilihat pada gambar 1.

\section{I-O Nelayan}

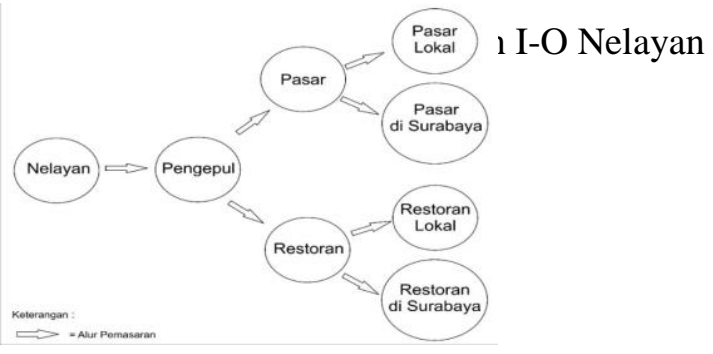

Gambar 1. Alur Pemasaran yang diterapkan oleh para Nelayan

Untuk para petani tambak hasil budidayanya antara lain : ikan bandeng dan udang. Sama halnya dengan para nelayan komoditas tersebut yang diandalkan oleh para petani tambak maupun buruh tambak untuk dijual ketika panen datang dan untuk memenuhi kebutuhan hidup sehari-hari. Mayoritas para petani tambak maupun buruh tambak dari hasil budidayanya disetor kepada pengepul yang biasanya mereka sebut dengan juragan. Dari juragan tersebut para petani tambak tidak tahu lagi hasil budidayanya dipasarkan kemana. Tetapi setelah saya menanyakan kepada beberapa pengepul/ juragan selanjutnya dari juragan ada yang dibawa ke restoran maupun pasar baik lokal maupun diluar Kabupaten Sidoarjo. Untuk lebih jelasnya bisa dilihat pada gambar 2 . 


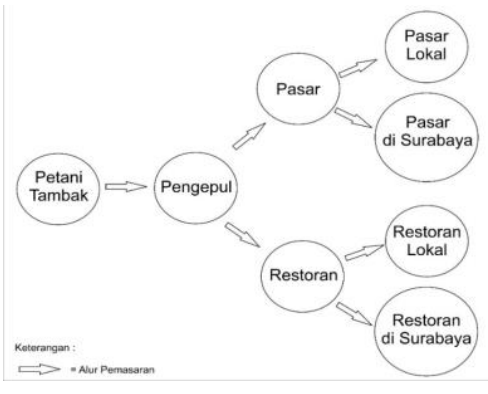

Gambar 2. Bagan I-O Petani Tambak

Ditinjau dari gambar 2. baik para nelayan maupun petani tambak dan dilihat dari partisipasi masyarakat yang ada di wilayah penelitian sangatlah kurang. Peran serta masyarakat diharapkan lebih aktif dalam mengembangkan potensi yang ada. Berdasarkan peninjauan dari gambar 2 melalui tangga partisipasi Sherry Arnstein bahwa wilayah penelitian ini berada pada level 2, Sherry Arnstein menjelaskan bahwa pada level 2 Terapi (therapy). Pada level ini telah ada komunikasi namun bersifat terbatas. Inisiatif datang dari pemerintah dan hanya satu arah. Untuk lebih jelasnya dapat dilihat pada gambar 3.

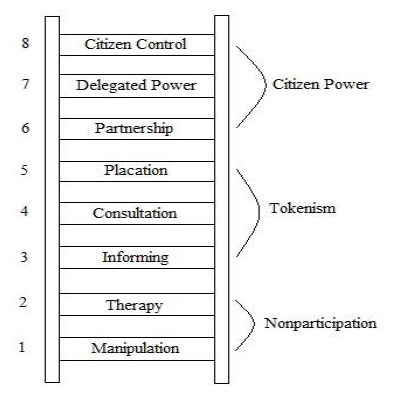

Gambar 3. Tangga Partisipasi Arnstein

\section{(1969)}

Berdasarkan tangga partisipasi dapat disimpulkan pada level 2 ini telah ada komunikasi namun bersifat terbatas. Inisiatif datang dari pemerintah dan hanya satu arah, kurangnya partisipasi masyarakat pada wilayah penelitian ini diharapkan masyarakat sekitar dapat lebih berperan aktif dalam pengembangan potensi yang ada sehingga sumberdaya alam yang ada dapat dimanfaatkan secara optimal dengan ada peran serta masyarakat yang aktif.

\section{Analisis SWOT}

Pengembangan potensi ekonomi kawasan pesisir di Kecamatan Sedati memerlukan strategi pengembangan, agar potensi yang ada di kawasan pesisir Kecamatan Sedati dapat dimanfaatkan oleh masyarakat sekitar dengan optimal. Selain itu dapat meningkatkan perekonomian masyarakat sekitar dan meningkatkan taraf hidup masyarakat kawasan pesisir Kecamatan Sedati. Terdapat beberapa faktor yang dapat mempengaruhi pengembangan potensi ekonomi kawasan pesisir Kecamatan Sedati diantaranya yaitu :

1. Potensi perikanan

2. Potensi budidaya

3. Potensi limbah hasil tangkapan para nelayan

4. Kurangnya Pemasaran terhadap hasil tangkapan nelayan maupun hasil budidaya 
5. Kurangnya sumber daya manusia, dilihat dari tingkat pendidikan masyarakat sekitar

6. Kurangnya pelatihan untuk pengolahan hasil tangkapan maupun limbah tangkapan para nelayan

7. Mahalnya harga pakan khususnya untuk budidaya

8. Kerjasama dengan pihak swasta masuk ke pasar yang lebih besar

9. Dukungan Pemerintah melalui pelatihan pengolahan hasil tangkapan nelayan

10. Dukungan Pemerintah melalui pelatihan pengolahan limbah hasil tangkapan nelayan
11. Kerjasama dengan pihak swasta untuk mengembangkan usaha para nelayan

12. Limbah pabrik yang dapat merusak ekosistem laut

13. Adanya komoditas sektor perikanan dari luar yang mempunyai kulitas yang lebih bagus

Berdasarkan faktor-faktor diatas akan dilakukan analisis faktor-faktor SWOT, dari faktor-faktor SWOT akan ditetapkan strategi faktor internal dan strategi faktor eksternal wilayah penelitian. Secara rinci akan dijelaskan pada tabel 2 .

Tabel 2. Matriks Analisis SWOT

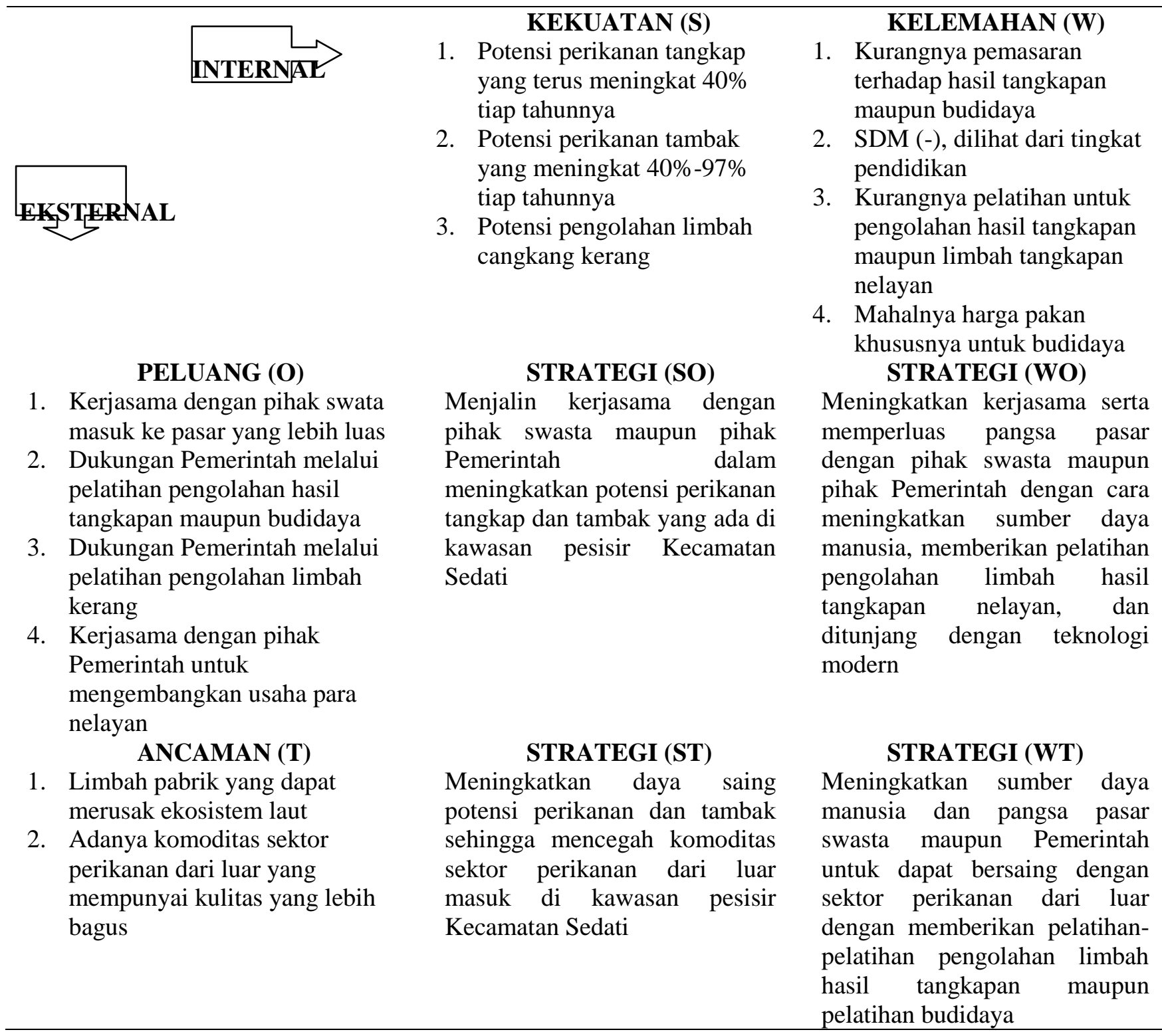


Berdasarkan tabel 2. telah ditetapkan yang menjadi faktor internal yaitu kekuatan (strengths) dan kelemahan (weakness), faktor eksternal yaitu peluang (Opportunities) dan ancaman (threats). Maka setelah dilakukan analisis SWOT, akan menghasilkan strategistrategi seperti diatas untuk dilakukan suatu pengembangan di wilayah penelitian. Dari hasil analisis matriks SWOT tersebut, telah dirumuskan empat strategi pengembangan pemberdayaan masyarakat di lokasi penelitian, yaitu :

a. Menjalin kerjasama dengan pihak swasta maupun pihak Pemerintah dalam meningkatkan potensi perikanan dan tambak yang ada di kawasan pesisir Kecamatan Sedati

Dengan adanya ketersediaan potensi sumberdaya alam kelautan maupun budidaya merupakan faktor-faktor yang seharusnya menjadi kekuatan untuk memanfaatkan peluang yang ada, yaitu dengan menjalin kerjasama dengan pihak Pemerintah maupun swasta.

b. Meningkatkan kerjasama serta memperluas pangsa pasar dengan pihak swasta maupun pihak Pemerintah dengan cara meningkatkan sumber daya manusia, memberikan pelatihan pengolahan limbah hasil tangkapan nelayan, dan ditunjang dengan teknologi modern

Dengan potensi yang ada, pemasaran merupakan hal yang paling menentukan berkembangnya potensi yang ada di suatu daerah. Dengan menjalin kerjasama dengan pihak Pemerintah maupun pihak swasta diharapkan potensi yang ada dapat berkembang. Pangsa pasar yang luas akan meningkatkan perekonomian serta meningkatkan kesejahteraan masyarakat di wilayah penelitian.

c. Meningkatkan daya saing potensi perikanan dan tambak sehingga mencegah komoditas sektor perikanan dari luar masuk di kawasan pesisir Kecamatan Sedati

Dengan meningkatkan dan mengembangkan potensi yang ada akan meminimalizir masuknya komoditas perikanan dari luar yang masuk di wilayah penelitian. Sehingga perlu dilakukan pengembangan daya saing untuk mencegah terjadinya hal tersebut.

d. Meningkatkan sumber daya manusia dan pangsa pasar swasta maupun Pemerintah untuk dapat bersaing dengan sektor perikanan dari luar dengan memberikan pelatihan-pelatihan pengolahan limbah hasil tangkapan maupun pelatihan budidaya. Merubah perilaku dan pola pikir masyarakat untuk meningkatkan sumberdaya manusia serta memperluas pangsa pasar harus ditunjang dengan peran Pemerintah maupun swasta untuk memberikan pelatihan-pelatihan untuk mengembangkan partisipasi masyarakat pesisir di wilayah penelitian.

\section{Analisis STEEP}

Analisa STEEP adalah suatu analisa dengan pendekatan yang lebih komprehensif dalam membantu mengolah data dari fakta yang sebenarnya terjadi untuk dipecahkan dan dicarikan solusinya. STEEP yang dianalisa adalah faktor yang menjadi analisis dari STEEP itu sendiri dalam perspektif pekerjaan ini yaitu :

$\mathrm{S}=$ Social, adalah permasalahan sosial yang sedang dan akan terjadi apabila masalah tidak segera diselesaikan.

$\mathrm{T}=$ Technological, yaitu teknologi apa yang akan digunakan dalam mengatasi permasalahan dalam proses kegiatan, yang mana teknologi tersebut sangat ditentukan oleh faktor pembiayaan.

$\mathrm{E}=$ Economic, yaitu suatu kondisi menyangkut ekonomi/ keuangan masya-rakat yang perlu dikaji sesuai dengan kebutuhan operasional dalam pengembangan potensi ekonomi.

$\mathrm{E}=$ Environment $/$ ecological, yaitu suatu kondisi menyangkut pengelolaan lingkungan sehubungan dengan potensi yang ada di kawasan pesisir Kecamatan Sedati.

$\mathrm{P}=$ Political, yaitu suatu kondisi yang menyangkut kepada politik pemerintah terkait dengan kebijakan Pemerintah Pusat dan Pemerintah Daerah

Berdasarkan penjelasan masing-masing faktor yang terdapat dalam analisis STEEP, maka matriks hasil identifikasi terhadap 
masing-masing faktor STEEP dikombinasikan dengan hasil matriks dari analisis SWOT.
Secara detail matriks kombinasi SWOTSTEEP sebagai berikut :

Tabel 3. Matriks Kombinasi Analisis SWOT-STEEP

STRENGTH (S) WEAKNESS (W) OPPORTUNITIES (O)

THREAT (T)

\begin{tabular}{ccl}
\hline $\begin{array}{l}\text { 1. Adanya } \\
\text { kelompok }\end{array}$ & $\begin{array}{l}\text { Kurangnya } \\
\text { partisipasi para } \\
\text { nelayan }\end{array}$ & $\begin{array}{l}\text { Meningkatkan sumber daya } \\
\text { manusia dan pangsa pasar swasta } \\
\text { maupun Pemerintah untuk dapat }\end{array}$ \\
SDOCIAL & $\begin{array}{l}\text { SDM (-), dilihat } \\
\text { dari tingkat } \\
\text { pendidikan }\end{array}$ & $\begin{array}{l}\text { bersaing dengan sektor perikanan } \\
\text { dari luar dengan memberikan } \\
\text { pelatihan-pelatihan pengolahan } \\
\text { limbah hasil tangkapan maupun } \\
\text { pelatihan budidaya } \\
\text { Perkembangan teknologi }\end{array}$ \\
TeCHNOLOG & $\begin{array}{l}\text { Teknologi } \\
\text { pengolahan }\end{array}$ &
\end{tabular}

1. Potensi

perikanan

tangkap yang

terus meningkat

$40 \%$ tiap

tahunnya

2. Potensi

perikanan

tambak yang

meningkat

40\%-97\% tiap

tahunnya

ECONOMIC

1. Potensi perikanan tangkap

2. Potensi perikanan tambak

ECOLOGY

POLITIC
1. Kurangnya industri pengolahan tangkapan nelayan

2. Kurangnya industri pengolahan limbah cangkang kerang

3. Kurangnya pemasaran terhadap hasil tangkapan maupun tambak

1. Kurangnya kesadaran akan keseha-tan penduduk

2. Nilai tembah ekonomi menurun akibat kondisi lingkungan yang kurang nyaman

1. Kurangnya pelatihan dari Pemerintah untuk pengolahan limbah cangkang kerang

2. Kurangnya dukungan Pemerintah
1. Keunikan atau kekhasan produk hasil tangkapan maupun budidaya dibandingkan kekhasan di daerah lainnya contohnya di daerah pesisir kenjeran Surabaya

2. Investasi

3.Meningkatkan daya saing potensi perikanan dan tambak sehingga mencegah komoditas sektor perikanan dari luar masuk di kawasan pesisir Kecamatan Sedati

1. Pengembangan potensi yang ada di kawasan pesisir Kecamatan Sedati

1. Kerjasama dengan pihak swata masuk ke pasar yang lebih besar

2. Kerjasama dengan pihak Pemerintah untuk mengembangkan usaha para nelayan

3. Menjalin kerjasama dengan pihak swasta maupun pihak Pemerintah dalam
1. Adanya Komoditas dari luar yang mempunyai kulitas yang lebih bagus

2. Mahalnya harga pakan khususnya untuk perikanan tambak

1. Limbah pabrik yang dapat merusak ekosistem laut 


\author{
khususnya \\ pemberian modal
}

meningkatkan potensi perikanan

dan tambak yang ada di

kawasan pesisir Kecamatan

Sedati

4. Meningkatkan kerjasama serta

memperluas pangsa pasar

dengan pihak swasta maupun

pihak Pemerintah dengan cara

meningkatkan sumber daya

manusia, memberikan pelatihan

pengolahan limbah cangkang

kerang, dan ditunjang dengan

teknologi modern
Berdasarkan hasil matriks kombinasi Analisis SWOT dan STEEP diperoleh beberapa strategi-strategi pengembangan, yaitu:

1. Sosial

Dalam aspek sosial yang ada pada Analisis STEEP memiliki kekuatan dengan adanya kelompok kelompok nelayan dapat memperkuat komunitas para nelayan, kelemahan sumber daya manusianya diharapkan dapat meningkatkan sumber daya manusia tersebut dan partisipasi masyarakat, peluang meningkatkan sumber daya manusia dan pangsa pasar swasta maupun Pemerintah untuk dapat bersaing dengan sektor perikanan dari luar dengan memberikan pelatihanpelatihan pengolahan limbah cangkang kerang maupun pelatihan perikanan tambak.

2. Teknologi

Aspek teknologi yang terdapat pada Analisis STEEP memiliki kelemahan dalam teknologi pengolahan, pengolahan limbah cangkang kerang khususnya. Dengan adanya kelemahan dalam aspek teknologi, maka memiliki peluang dalam hal perkembangan teknologi dalam hal teknologi pengolahan limbah cangkang kerang.

3. Ekonomi

Dengan adanya potensi perikanan tangkap yang terus meningkat $40 \%$ tiap tahunnya dan potensi perikanan tambak yang meningkat $40 \%-97 \%$ tiap tahunnya sehingga dapat meningkatkan daya saing potensi perikanan dan tambak sehingga mencegah komoditas sektor perikanan dari luar masuk di kawasan pesisir Kecamatan Sedati serta kurangnya pemasaran hasil perikanan tangkap maupun perikanan tambak. Dengan demikian dapat menekan masuknya komoditas perikanan dari luar masuk ke dalam kawasan pesisir Kecamatan Sedati.

4. Ekologi

Dalam aspek Ekologi memiliki kekuatan potensi perikanan tangkap dan potensi perikanan tambak. Kurangnya kesadaran akan kesehatan dan nilai ekonomi menurun akibat kondisi lingkungan yang kurang nyaman ditambah lagi dengan adanya buangan limbah pabrik yang dapat merusak ekosistem laut. Dengan demikian adanya peluang untuk dilakukan pengembangan potensi di kawasan pesisir Kecamatan Sedati.

5. Politik

Kurangnya pelatihan serta dukungan dari Pemerintah merupakan faktor kelemahan dalam aspek politik yang ada pada Analisis STEEP. Sehingga dengan kelemahan yang ada, peluang untuk kerjasama dengan pihak Pemerintah maupun swasta untuk memberikan pelatihan maupun dukungan untuk memperluas pangsa pasar dalam pengembangan potensi ekonomi kawasan pesisir Kecamatan Sedati.

Dengan demikian dapat disimpulkan ada prioritas utama aspek yang perlu dikembangkan terlebih dahulu yaitu aspek sosial. Dengan cara meningkatkan sumber daya manusia masyarakat kawasan pesisir 
Kecamatan Sedati. Dengan adanya peningkatan sumber daya manusia maka masyarakat lebih siap menghadapi teknologi yang ada, masyarakat lebih siap mengembangkan potensi yang ada, kesadaran masyarakat akan kesehatan dan lebih peduli terhadap lingkungan, serta masyarakat akan lebih siap untuk bekerja sama dengan pihak Pemerintah maupun swasta untuk mengembangkan potensi yang ada.

\section{Pembahasan}

Pengembangan potensi di suatu daerah dipengaruhi dengan adanya tingkat sumberdaya manusia yang ada di suatu daerah tersebut. Wilayah penelitian ini terletak di kawasan pesisir, dimana kawasan pesisir identik dengan masyarakat yang memiliki tingkat sumberdaya manusia yang rendah. Masyarakat yang ada di wilayah penelitian rata-rata menempuh pendidikan terakhir Sekolah Dasar (SD) hingga Sekolah Menengah Atas (SMA). Mayoritas masyarakat yang ada di wilayah penelitian menempuh pendidikan terakhir Sekolah Dasar (SD). Lebih jelasnya dapat dilihat pada grafik 1 .

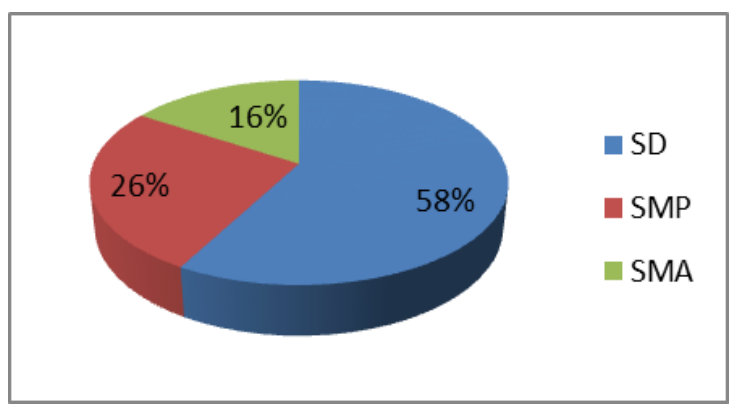

Grafik 1. Tingkat Pendidikan Wilayah Penelitian

Dari grafik 1. dapat disimpulkan bahwa prosentase terbesar ialah masyarakat dengan pendidikan terakhir tamatan Sekolah Dasar (SD). Prosentase terendah yaitu masyarakat dengan tamatan Sekolah Menengah Atas (SMA).

Kecamatan Sedati memiliki karakteristik wilayah pesisir karena letaknya berada pada titik pertemuan antara daratan dan lautan. Masyarakat pesisir identik dengan masyarakat yang mempunyai pekerjaan sebagai nelayan. Dengan didukung karakteristik wilayah yang ada, mayoritas masyarakat di wilayah penelitian ini bekerja sebagai nelayan maupun petani tambak. Lebih jelasnya dapat dilihat pada grafik 2 .

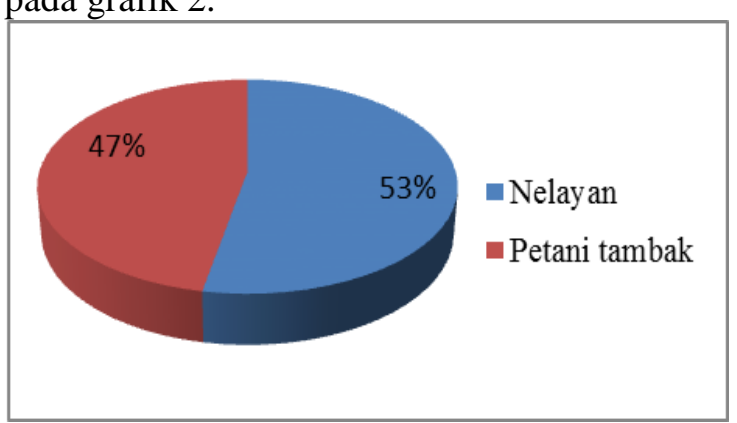

Grafik 2. Mata Pencaharian Wilayah
Penelitian

Berdasarkan grafik 2. diperoleh perbandingan prosentase mata pencaharian di wilayah penelitian yaitu $53 \%$ bekerja sebagai nelayan dan $47 \%$ bekerja sebagai petani tambak. Hal ini dipengaruhi dengan tingkat pendidikan masyarakat yang bekerja sebagai nelayan maupun petani tambak.

Mata pencaharian penduduk di kawasan pesisir Sedati ialah mayoritas sebagai nelayan. Mata pencaharian tersebut menghasilkan tangkapan hasil laut. Hasil tangkapan tersebut akan dipasarkan di Kecamatan Sedati khususnya maupun di luar Kecamatan Sedati. Nelayan yang ada di kawasan pesisir Sedati menjual hasil tangkapannya kepada para tengkulak maupun pengepul. Lebih jelasnya dapat dilihat pada grafik 3 .

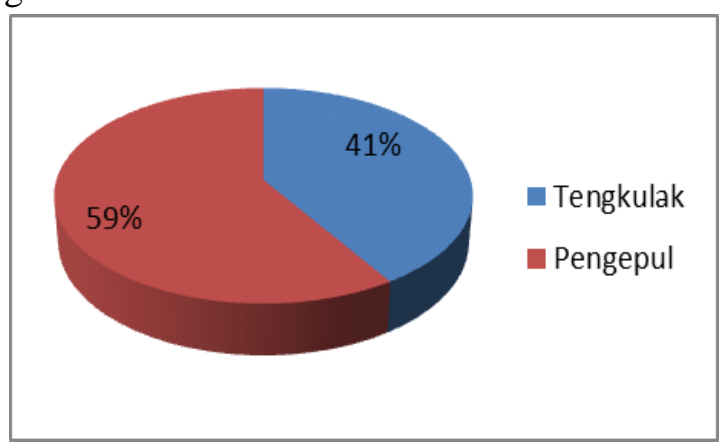

Grafik 3. Pembeli Hasil Tangkapan Nelayan

Berdasarkan grafik 3. dapat disimpulkan prosentase terbesar ialah nelayan yang menjual hasil tangkapannya kepada para 
pengepul. Pengepul yang dimaksud yaitu juragan bagi para nelayan dan setiap nelayan mendapatkan hasil tangkapan harus dijual kepada juragan tersebut.

Dapat disimpulkan melalui penjelasan diatas, maka pengembangan potensi ekonomi di kawasan pesisir Sedati yang paling utama dipengaruhi dengan tingkat pendidikan yang rendah. Tingkat pendidikan yang rendah akan mempengaruhi jenis pekerjaan masyarakat. Dengan tingkat pendidikan yang ada dan didukung dengan letak geografis yang berada pada kawasan pesisir, masyarakat sekitar bekerja sebagai nelayan maupun petani tambak.

Melalui hasil tangkapan para nelayan dapat melangsungkan hidup dan memenuhi kebutuhan hidup sehari-hari. Kurangnya pemasaran hasil tangkapan para nelayan yang hanya mengandalkan para pengepul atau juragan, dapat disimpulkan bahwa kurangnya partisipasi masyarakat.

\section{KESIMPULAN}

Dari uraian tersebut di atas, dapat diambil kesimpulan sebagai berikut :

1. Hasil dari Analisis Skalogram menunjukkan bahwa potensi ekonomi yang yang ada di kawasan pesisir Kecamatan Sedati ialah sektor perikanan tambak yang ada di Desa Kalanganyar. Terbukti dari hasil Analisis Skalogram Desa Kalanganyar mendapatkan peringkat I. Sarana prasarana merupakan aspek yang paling utama dalam kegiatan sosial atau kegiatan ekonomi. Desa Kalanganyar terletak paling dekat dengan Kecamatan Sedati, mudah dijangkau dari Kota/ Kabupaten Sidoarjo. Ditinjau dari akses jalannya yang mudah juga memudahkan untuk akses keluar masuk distribusi apapun. Akses transportasi yang mudah juga mempengaruhi proses pemasaran dari potensi ekonomi yang ada di Desa Kalanganyar.

2. Dari kesimpulan tangga partisipasi bahwa partisipasi masyarakat kawasan pesisir Kecamatan Sedati berada pada level 2, Sherry Arnstein menjelaskan bahwa pada level 2 Terapi (therapy). Pada level ini telah ada komunikasi namun bersifat terbatas. Inisiatif datang dari Pemerintah dan hanya satu arah. Kurangnya partisipasi masyarakat kawasan pesisir Kecamatan Sedati diharapkan masyarakat sekitar dapat lebih berperan aktif dalam pengembangan potensi yang ada sehingga sumberdaya alam yang ada dapat dimanfaatkan secara optimal dengan adanya peran serta masyarakat yang aktif.

3. Hasil dari kombinasi Analisis SWOT dan STEEP ada prioritas utama aspek yang perlu dikembangkan terlebih dahulu yaitu aspek sosial. Dengan cara meningkatkan sumber daya manusia masyarakat kawasan pesisir Kecamatan Sedati. Dengan adanya peningkatan sumber daya manusia maka masyarakat lebih siap menghadapi teknologi yang ada, masyarakat lebih siap mengembangkan potensi yang ada, kesadaran masyarakat akan kesehatan dan lebih peduli terhadap lingkungan, serta masyarakat akan lebih siap untuk bekerja sama dengan pihak Pemerintah maupun swasta untuk mengembangkan potensi yang ada.

\section{Ucapan Terima Kasih}

Ucapan terimakasih disampaikan kepada BAPPEDA Sidoarjo yang telah membantu data-data sekunder dan masyarakat pesisir Kecamatan Sedati Kabupaten Sidoarjo yang telah berpartisipasi sebagai responden terpilih.

\section{DAFTAR PUSTAKA}

Budiharsono, Sugeng. 2001. Teknik Analisis Pembangunan Wilayah Pesisir. Pradnya Paramita. Jakarta.

Nurwahyuni, Lia P. 2007. Penentuan Prioritas Pengembangan Kawasan Pesisir Kecamatan Sedati. Skripsi. Jurusan Perencanaan Wilayah dan Kota Fakultas Teknik Sipil dan Perencanaan. ITS. Surabaya.

STEEP Analisis Suning, SE,. MT,. (2013)

Undang-Undang Tata Ruang Republik Indonesia No. 26 tahun 2007

Undang-Undang No. 27 tahun 2007 tentang pengelolaan wilayah pesisir dan pulau-pulau kecil. 